\title{
The stratigraphy and geochemistry of late Devonian to early Carboniferous volcanic rocks of the northern Chignecto peninsula, Cobequid Highlands, Nova Scotia
}

\author{
David J.W. Piper ${ }^{1}$, Georgia Pe-Piper ${ }^{2}$ and David J. Pass ${ }^{2}$ \\ 1 Atlantic Geoscience Centre, Geological Survey of Canada (Atlantic), \\ Bedford Institute of Oceanography, P.O. Box 1006, Dartmouth, Nova Scotia B2Y 4A2, Canada \\ 2Department of Geology, Saint Mary's University, Halifax, Nova Scotia B3H 3C3, Canada
}

Date Received May 31, 1995

Date Accepted October 11, 1995

\begin{abstract}
The volcanic succession of the Fountain Lake Group of the northern Chignecto peninsula consists of basalt and andesite flows, rhyolite shallow intrusions and minor flows, and rhyolitic pyroclastic rocks. Fault scarp breccia, fluvial conglomerate and sandstone, and lacustrine siltstone and minor limestone are interbedded with the volcanic rocks. The succession is cut by mafic dykes, some of which predate and others postdating brittle northvergent thrusting. Detailed geochemical and petrographic study shows that the volcanic rocks geochemically resemble the plutonic rocks of the Cape Chignecto pluton that are thrust over the volcanic succession. Diabase dykes may record the contamination of gabbroic magma by residual base-of-crust plagioclase-pyroxene granulite from which felsic magma had been extracted. Fractionation of this mafic magma resulted in enrichment in incompatible elements in some dykes. Andesites evolved from basaltic parents either by fractionation or by melting of hydrous gabbros. Much of the volcanic succession shows low-temperature alteration including silicification.
\end{abstract}

La succession volcanique du Groupe du lac Fountain dans la partie septentrionale de la péninsule de Chignecto comprend des écoulements de basalte et d'andésite, des intrusions peu profondes de rhyolite et des écoulements mineurs, de même que des roches pyroclastiques rhyolitiques. Des brèches d'escarpements de failles, du grès et un conglomérat fluvial, ainsi que du siltsone lacustre et une faible quantité de calcaire sont interstratifiés de roches volcaniques. La succession est entrecoupée par des filons intrusifs mafiques, dont certains sont antérieurs et d'autres postérieurs à une poussée fragile orientée vers le nord. Une étude géochimique et pétrographique détaillée montre que les roches volcaniques ressemblent géochimiquement aux roches plutoniques de l'intrusion ignée de Cape Chignecto qui recouvrent la succession volcanique. Des filons intrusifs diabasiques peuvent enregistrer la contamination du magma gabbroïque par la granulite résiduelle de plagioclase-pyroxène de la base de la croute de laquelle du magma felsique avait été extrait. Le fractionnement de ce magma mafique a produit un enrichissement en éléments incompatibles de certains filons intrusifs. Les andésites ont évolué à partir de parents basaltiques, par fractionnement ou par fusion de gabbros aqueux. Une vaste part de la succession volcanique révèle une altération, notamment une silicification, à basse température.

[Traduit par la rédaction]

\section{INTRODUCTION}

A series of rhyolites, andesites and basalts, cut by large mafic dykes, outcrop in coastal sections northwest of the Cape Chignecto pluton (Fig. 1), from Seal Cove through Eatonville Cove and Squally Point to Spicers Cove (Fig. 2). The sections from Eatonville Cove to Spicers Cove are accessible at low tide, but sections further south are difficult to access, except in the area immediately north of Seal Cove. Inland, these rocks are well exposed only in Eatonville Brook.

These rocks have been generally regarded as part of the Fountain Lake Group forming volcanic equivalents to the Cape Chignecto pluton. Piper et al. (1993) described northwest-vergent thrust structures in the volcanic sequence similar to those recognised in the Cape Chignecto pluton (Waldron et al., 1989).

The purpose of this work was to define the stratigraphy of the volcanic sequence and use this stratigraphy to better understand the order of structural events (faulting and dyke injection) and the petrological and geochemical evolution of the sequence. The Squally Point area has $100 \%$ cliff exposure and significant exposure along the beach. It is the only location in the Cobequid Highlands of high quality outcrop of Fountain Lake volcanic rocks.

\section{Methods}

The entire accessible coastal section and the Eatonville Brook were traversed and selected areas near Squally Point, in Eatonville Cove and north of Seal Cove were mapped at 1:2000 scale. Particular attention was paid to cross-cutting relationships between igneous rocks and structures, in order to develop a sequence of events. More than 100 thin sections were examined. Chemical analyses of representa- 


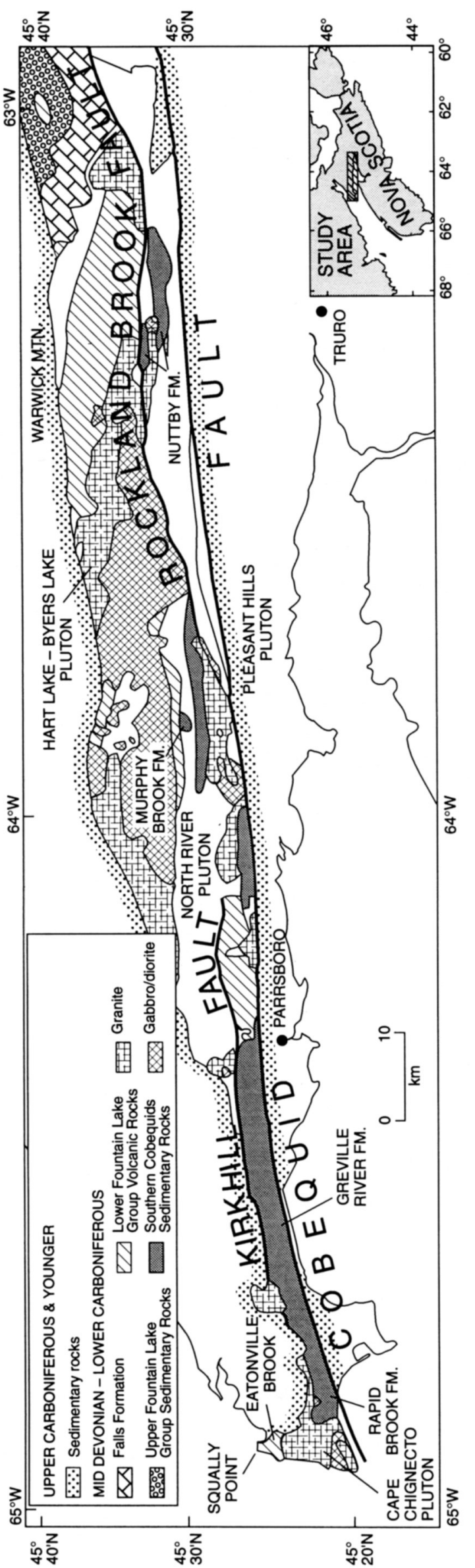

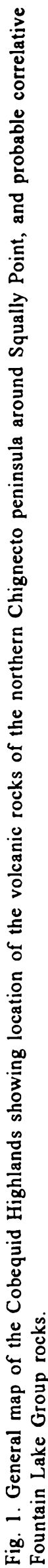

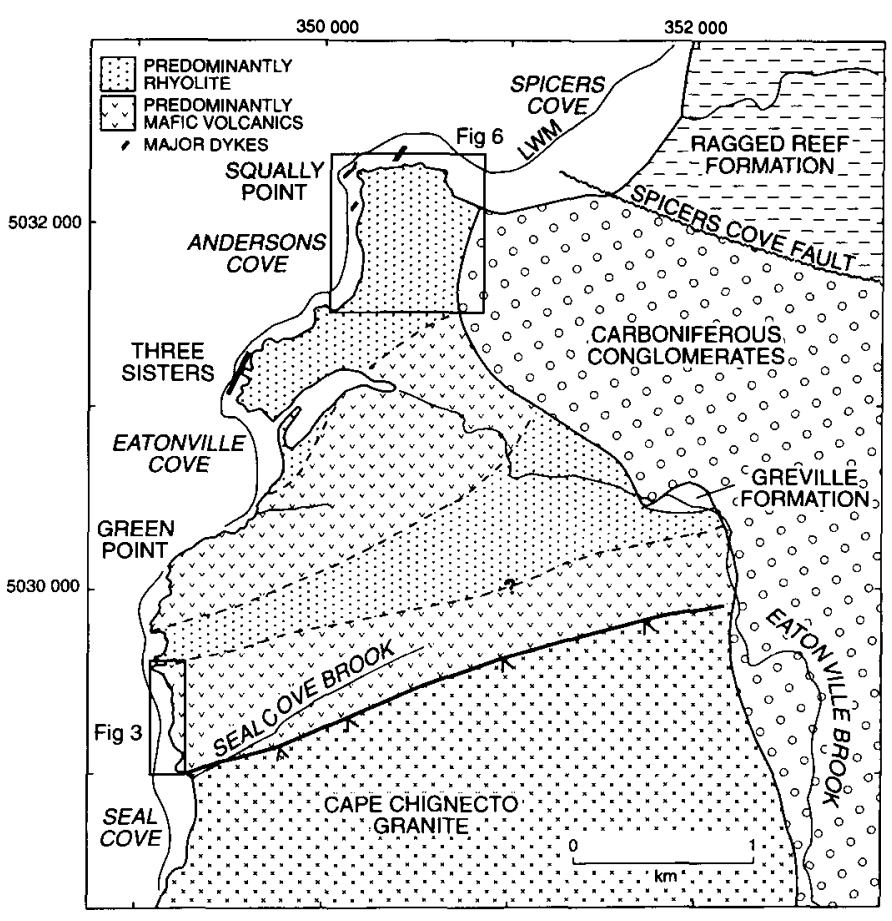

Fig. 2. General map of the northern Chignecto peninsula. Based on Donohoe and Wallace (1982) and Ryan et al. (1990), modified by our own mapping.

tive rocks were made by XRF and INAA at the Saint Mary's University Regional Analytical Centre: analytical methods are described in detail by Pe-Piper and Piper (1989). Some samples were assayed by INAA for $\mathrm{Au}, \mathrm{As}, \mathrm{Br}$ and other elements by X-Ray Assay Laboratories Limited.

\section{General GeOlogy}

\section{Introduction}

The northern margin of the Cape Chignecto pluton is exposed in Seal Cove (Fig. 2), where the granite is thrust over a thin slice of cherty phyllite, probably of the Neoproterozoic Jeffers Group, which in turn overthrusts a sequence of stratified volcanic rocks and interbedded sediments, intruded by porphyritic rhyolite and mafic sills and dykes. About $700 \mathrm{~m}$ north of Seal Cove, in an inaccessible cove, there is a large apparently intrusive body of porphyritic rhyolite cut by mafic dykes. Further north, to the northeast of Green Point, subhorizontal basalt flows interbed with rhyolite, pyroclastic and volcaniclastic sediment. In Eatonville Cove and at the Three Sisters to the north, the predominant rock type is porphyritic and flow banded rhyolite. This succession is cut by some major north-south trending dykes, with complex pull-apart structures illustrated by Piper et al. (1993). Similar dykes are found at Squally Point. Between Anderson Cove and Squally Point, these rhyolites pass stratigraphically upward into hyaloclastitic rhyolite, lithic-crystal tuffs, minor sediments and thin andesite, dipping generally north or northeast. In Spicers Cove, the volcanic rocks are overlain 
unconformably by coarse red conglomerates of an unknown Carboniferous age (Salas, 1986). These conglomerates also unconformably overlie rocks assigned to the Greville River Formation in Eatonville Brook. The conglomerates are in fault contact with the Westphalian Ragged Reef Formation (Ryan et al., 1990).

The entire volcanic succession from Seal Cove to Spicers Cove is cut by north-vergent thrusts and by numerous mafic dykes, some of which pre-date and some of which post-date the thrusting. The volcanic pile is substantially altered: mafic volcanic rocks are in places highly silicified and some rhyolites show strong ochre-weathering characteristic of sulphides. Later faults have barite mineralisation.

\section{Section north of Seal Cove}

The section for $700 \mathrm{~m}$ north of Seal Cove is accessible at low tide and has been mapped in detail (Fig. 3). It consists of a dismembered sequence of basalt and rhyolite flows and interbedded sediments that has been intruded by hypabyssal porphyritic rhyolite, diabase sills, and later diabase dykes. Most of the sequences of flows and sedimentary rocks dip steeply southward, and individual packets between faults are $<25 \mathrm{~m}$ thick.

At the southern end of the section, the sequence is substantially tectonised, apparently as a result of thrusting of the Cape Chignecto granite northwards over the volcanic rocks. The deformed rocks include cherty phyllite. These are tentatively correlated with the Neoproterozoic Jeffers Group, which forms the pre-Carboniferous basement in the western Cobequid Highlands. Alternatively, they may be silicified sediments of the northern Chignecto peninsular volcanic suite.

Basalts are massive to rubbly, with common vesicles, particularly at the tops of flows. Flow tops tend to be purplish in colour. Most of the basalts show patchy silicification, in places in subvertical pipes (Fig. 5A). Tops of some flows are highly silicified. Several flows are overlain by red mudstones, and in some cases xenoliths of red mudstone occur at the base of flows.

Some rhyolites are clearly flows that conformably overlie basalt flows. In places, flow banded rhyolites outcrop. The most common rhyolitic lithology is a finely porphyritic rhyolite, which at two localities is seen to intrude basalt.

Sediments interbedded with the basalt and rhyolite flows range from coarse breccia to mudstone. In the central part of the section, a continuous stratigraphic section could be measured (Fig. 4). Some breccias contain clasts of rhyolite up to several metres in maximum dimension (Fig. 5B). They interbed with finer volcaniclastic conglomerate and sandstone and rare thin limestone. Sericitic siltstones occur in beds 0.5 to $2 \mathrm{~cm}$ thick and show wavy lamination and rare shallow scours. Red sandstones, siltstone and mudstones are generally massive or poorly bedded.

Diabase sills* are quite variable in thickness, but are

"The term "sill" is used for thick sub-horizontal mafic sheets, in contrast to steeply dipping dykes.

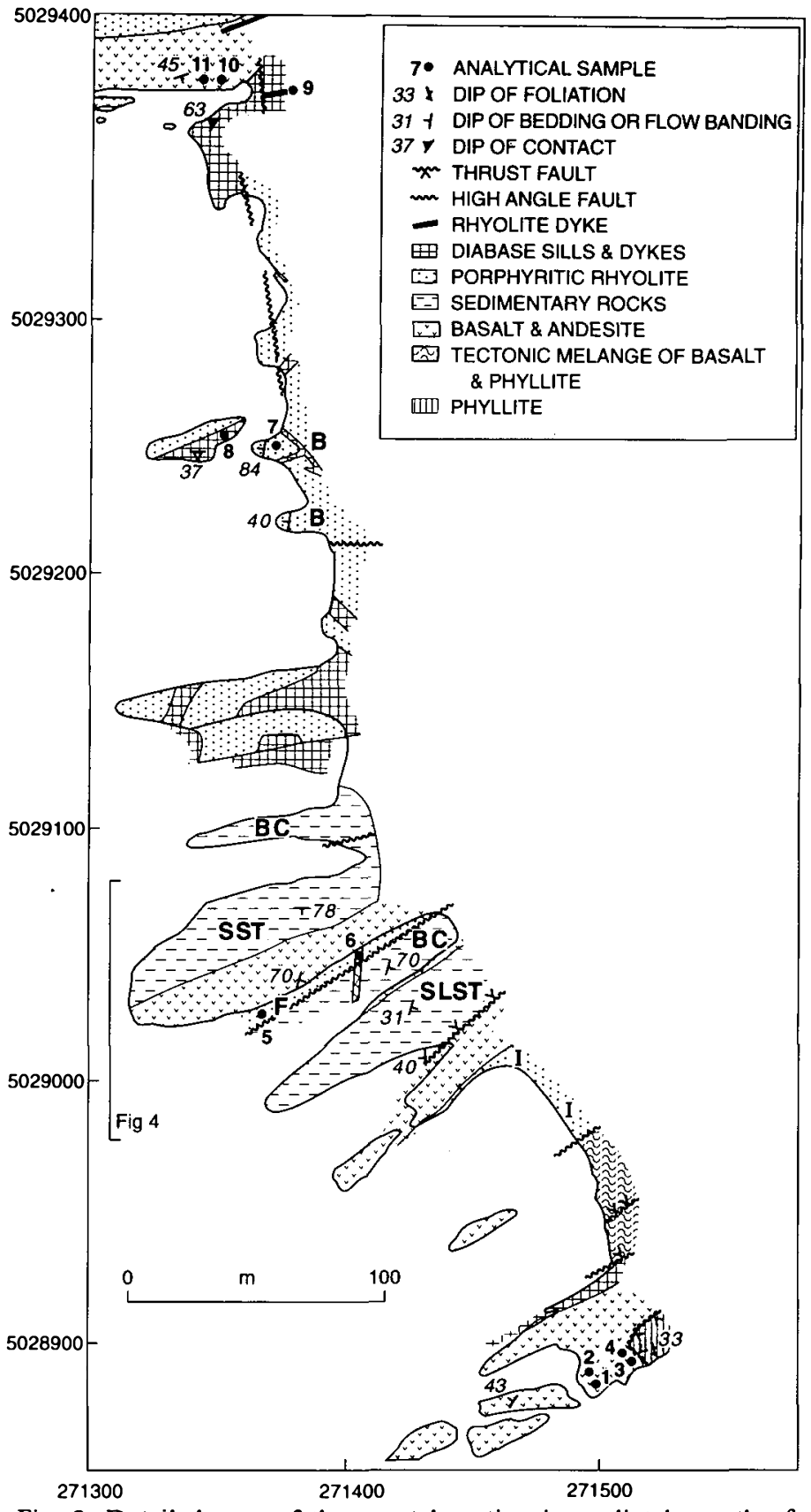

Fig. 3. Detailed map of the coastal section immediately north of Seal Cove. $\mathrm{BC}=$ breccia, SST = sandstone and breccia with $\mathrm{mi}$ nor interbedded limestone, SLST = siltstone, $\mathrm{B}=$ flow banded rhyolite, $\mathrm{F}=$ rhyolite flow, $\mathrm{I}=$ intrusive rhyolite. Shows location of analytical samples in Table 1 .

up to $11 \mathrm{~m}$ thick. In places, they show columnar jointing. Most dip gently to the south or east at a lesser dip than the sediments and flows. Rare diabase dykes cut both the sills and the steeply dipping sediments and flows. One rhyolite dyke cuts a sill.

\section{Section east of Green Point}

A small brook east of Green Point provides access at low tide to a short length of coastal exposure between Green Point and Eatonville Cove. It comprises subhorizontal basalt and rhyolite flows and pyroclastic and volcaniclastic 


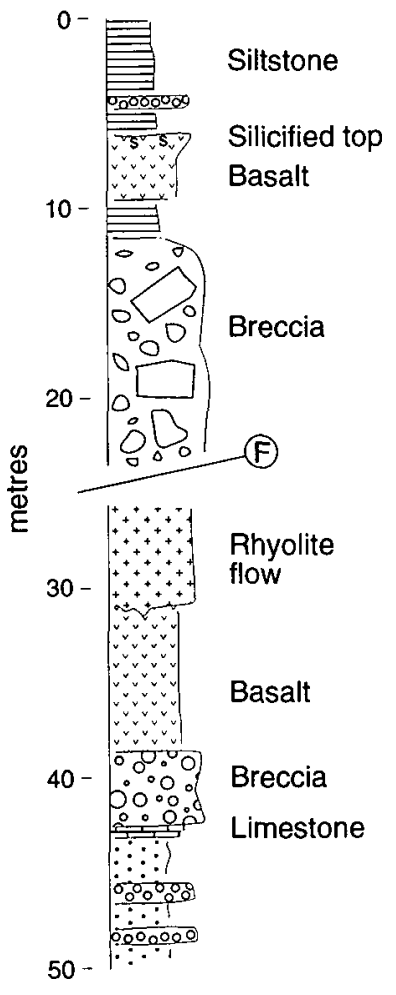

Fig. 4. Measured stratigraphic section through sedimentary rocks in the area north of Seal Cove. Location shown on Figure 3.
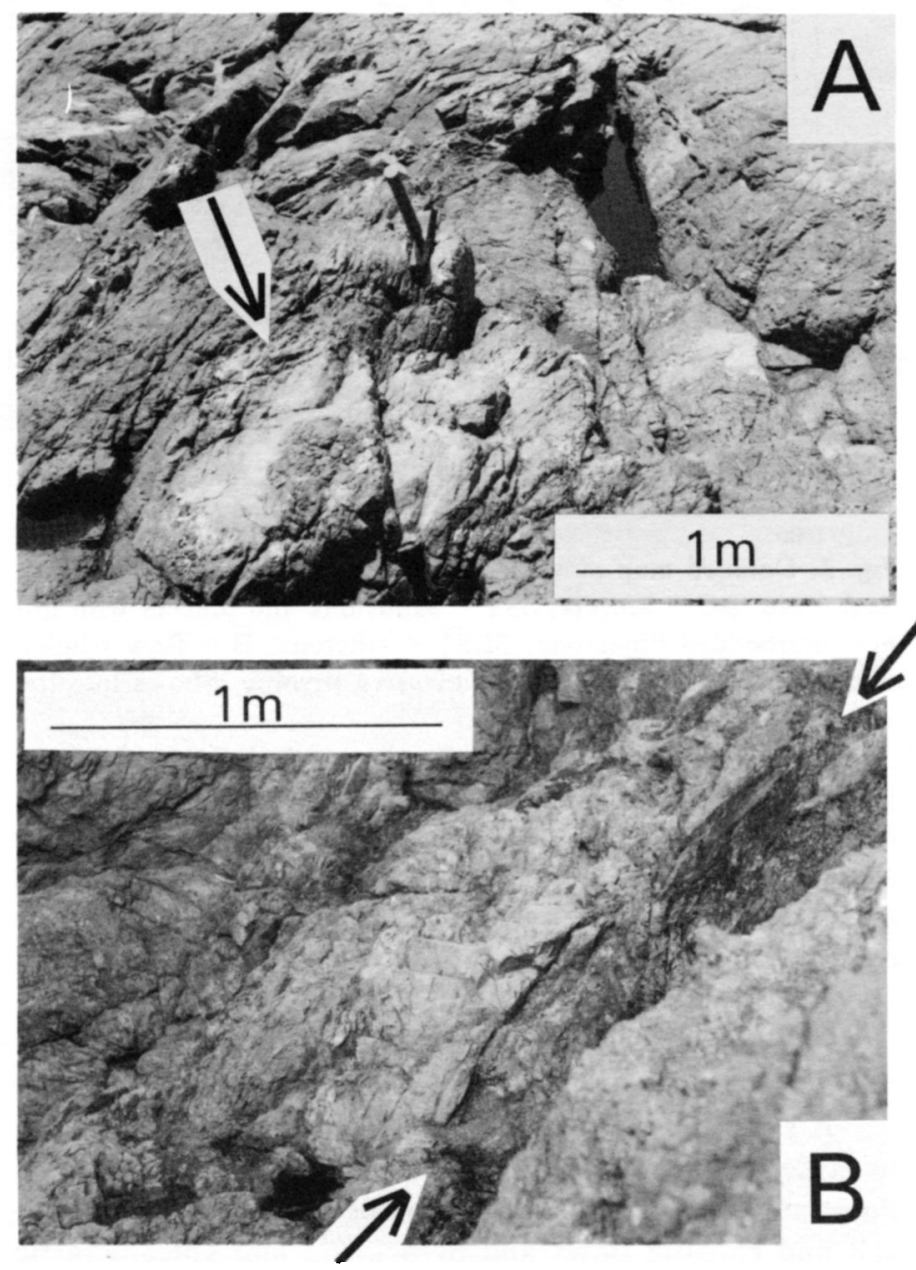

sediments. The basalts are massive to vesicular. The rhyolites include lithic-crystal tuffs and massive porphyritic rhyolites. The sediments include poorly sorted coarse conglomerates of basaltic or rhyolitic clasts interpreted as lahars. Passing northeastward towards Eatonville Cove, the proportion of rhyolite increases. This appears to represent an upward stratigraphic passage, but numerous faults and the inaccessibility of the coast make this interpretation tenuous.

\section{Eatonville Brook and Cove}

Eatonville Brook exposes a series of basalt and andesite flows, interbedded with minor flow-banded rhyolite and cut by mafic dykes. This predominantly mafic succession passes upstream into pyroclastic, porphyritic intrusive and flow banded rhyolite. Outcrop is insufficient to discern overall structure or to determine where these rocks fit in an overall stratigraphic sequence.

In Eatonville Cove and northward to Anderson Cove, the rocks consist principally of porphyritic rhyolite, with minor flow banded rhyolite that dips gently to the northwest. The rhyolites are cut by a major diabase dyke up to 20 $m$ wide (illustrated`as figure 5 of Piper et al., 1993).

\section{Squally Point}

The volcanic rocks around Squally Point (Fig. 6) form a 100-m-thick stratigraphic section, with the youngest rocks exposed in the northwest. The section is complicated by a series of flat-lying thrust faults with northerly vergence, most of which probably have offsets of only a few metres or decametres. Stratigraphic continuity is also interrupted by numerous high-angle faults. Diabase dykes are both cut by and occupy space created by the thrusting (Piper et al., 1993, their figure 4). As at Eatonville, the large dykes show pullapart relationships suggesting east-west extension (Piper $\boldsymbol{e t}$ al., 1993, their figure 6).

The oldest volcanic rocks are porphyritic rhyolites exposed in Spicers Cove and southern Anderson Cove. They are overlain by 3 to $5 \mathrm{~m}$ of flow banded rhyolite (Fig. 7). South of Squally Point, a 4-m-thick poorly sorted conglomerate interpreted as a lahar rests on an irregular surface over the flow banded rhyolite. The lahar contains $<50 \mathrm{~cm}$ blocks of reworked rhyolite in a fine grained hematized matrix.

The overlying rhyolites are typically green in colour and have a cumulative thickness south of Squally Point of about $50 \mathrm{~m}$. Many are coarsely spherulitic and interbedded with brecciated and hyaloclastic rhyolites (Fig. 8A), in places with lithophysae (Fig. 8B). This succession is overlain by one or more andesitic flows. One of the higher flows south of Squally Point shows pillow structures. The uppermost flow is deeply weathered and somewhat silicified. The andesite flows are locally both underlain and overlain by a discontinuous clast-supported conglomerate and pebbly sandstone.

Fig. 5. Photographs illustrating lithologies north of Seal Cove. (A) Silicified pipe (arrow: lighter colour) and patchy silicification in basalt. (B) large rhyolite clast in breccia. Scales are approximate. 


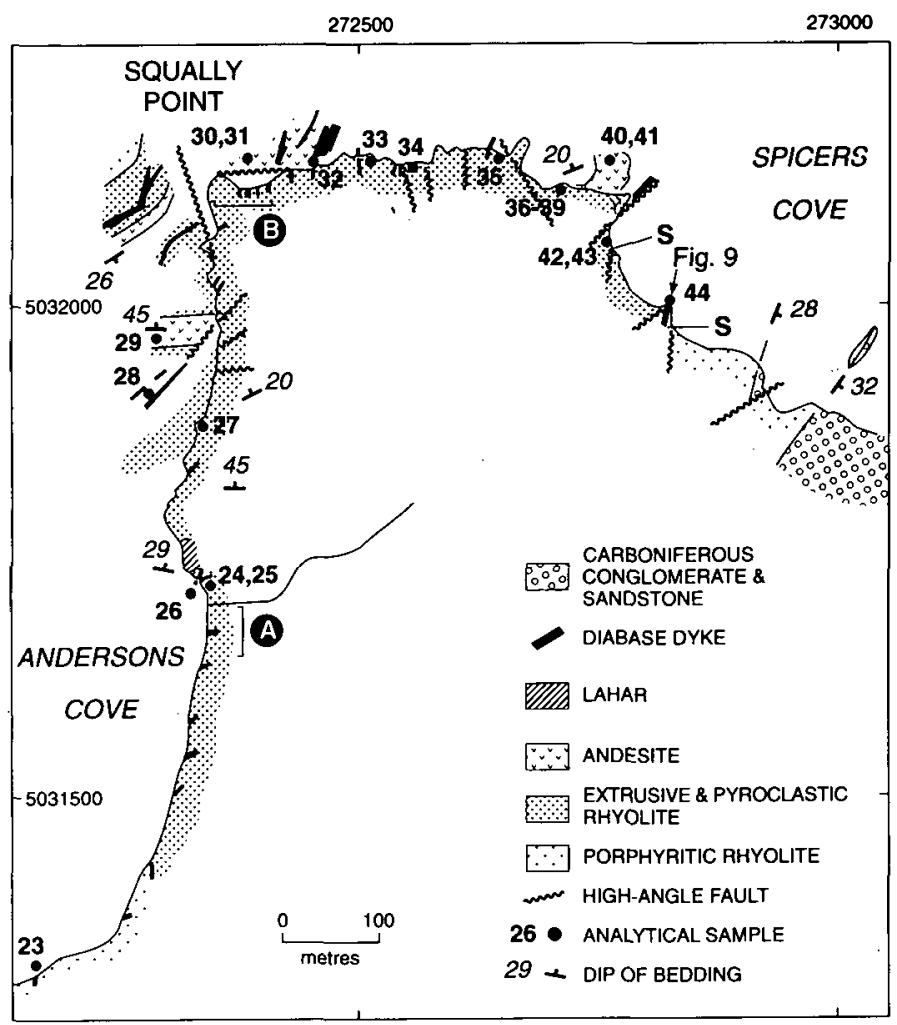

Fig. 6. Detailed geological map of the Squally Point area, showing location of analytical samples in Table $1 . \mathrm{S}=$ slices of breccia along wrench faults. (A) = figure 4 of Piper et al. (1993); (B) = figure 6 of Piper et al. (1993).

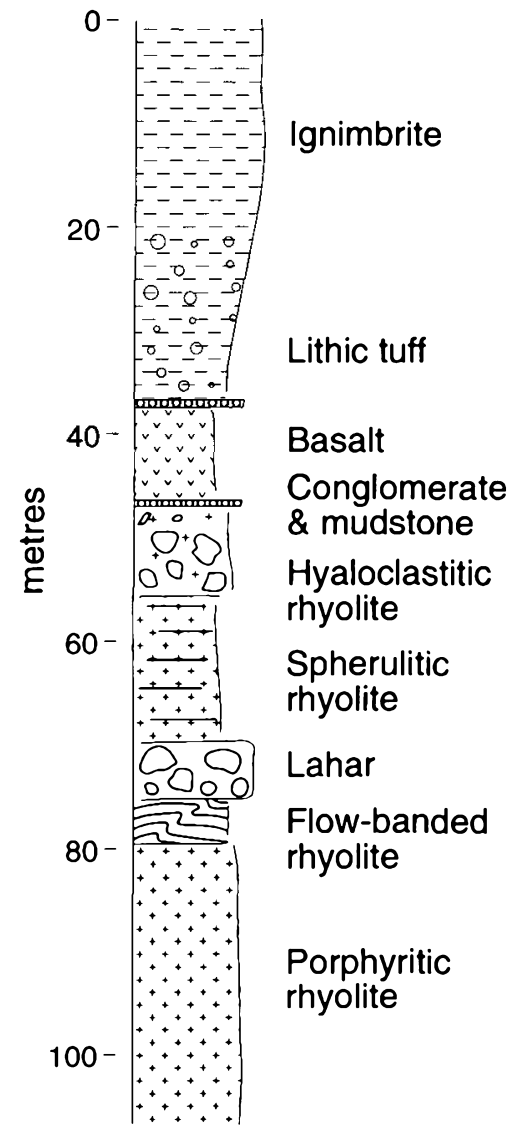

Fig. 7. Measured stratigraphic section from Andersons Cove north to Squally Point.
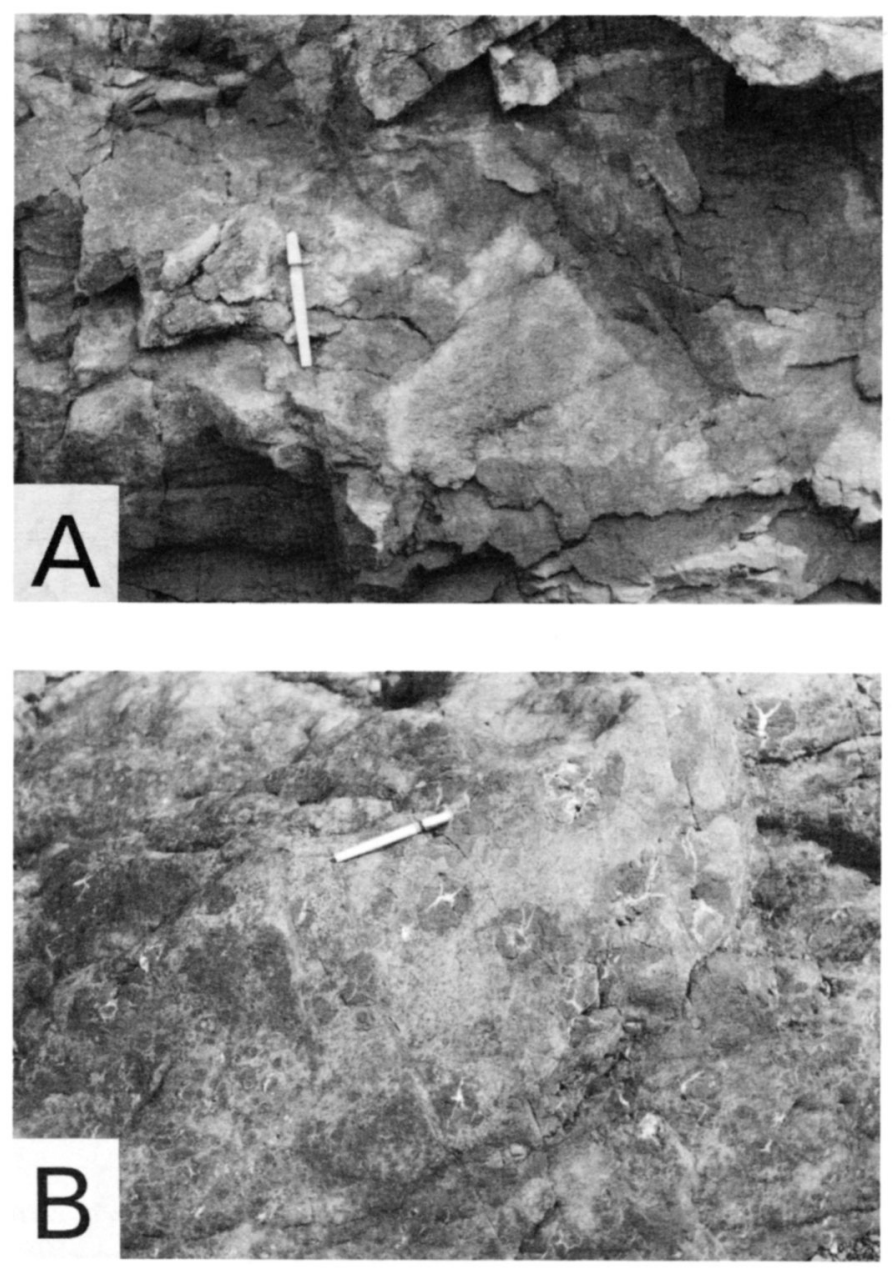

Fig. 8. Photographs illustrating hyaloclastitic rhyolite south of Squally Point. (A) Angular devitrified blocks in hyaloclastitic matrix. (B) Lithophysae in fragmental rhyolite. Pen is $13.5 \mathrm{~cm}$ long.

The andesite unit is overlain by thin vitreous rhyolite and then a 40-m-thick felsic pyroclastic succession. The basal $20 \mathrm{~m}$ consists of lithic tuff, with an upward decrease in the abundance of lithic fragments. It is overlain by a 20 -m-thick ignimbrite.

At the western end of Spicers Cove, porphyritic rhyolite is unconformably overlain by Carboniferous conglomerates that contain a wide range of igneous clasts including flow-banded rhyolite, diabase, foliated diorite and granite and undeformed granite. Cleaved green cherty siltstone clasts are also found, similar to the ? Jeffers Group exposed at Seal Cove.

About $100 \mathrm{~m}$ northwest of the unconformity, slivers of steeply dipping coarse clastic sediment are preserved along north-trending high-angle faults ( $\mathrm{S}$ in Fig. 6). The relationships are seen most clearly at the outcrop illustrated in Figure 9, where a coarse diabase dyke (sample 44) with chilled margins was intruded along a fault that bounded a 3-m thick sediment sequence. The faults that bound the sediment sequence separate porphyritic rhyolite in the east from flatlying flow-banded rhyolite in the west. The sedimentary rocks are subvertical, young to the east and consist of (a) a ma- 


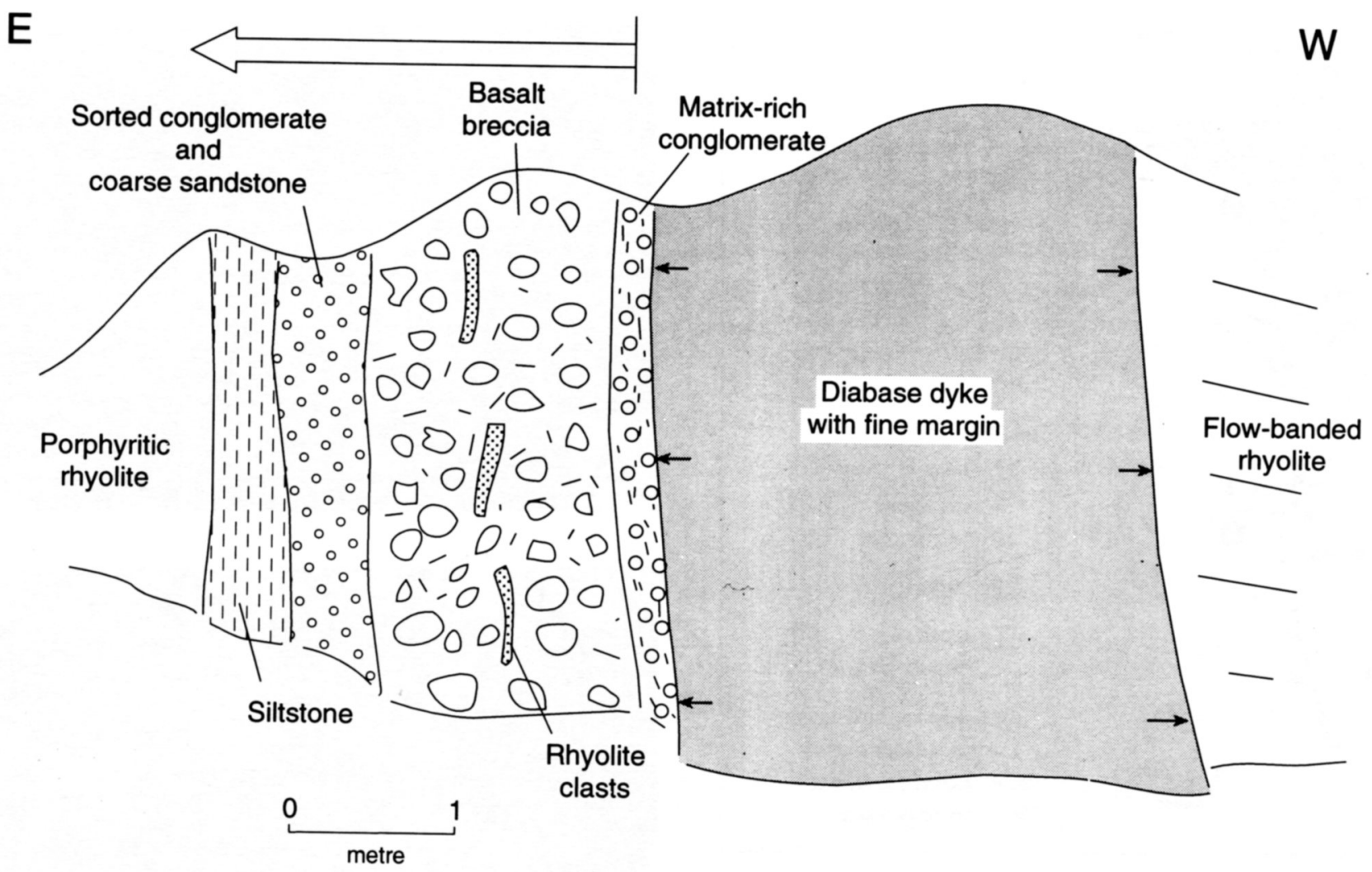

Fig. 9. Sketch of field relationships of diabase dyke and fault-bounded sedimentary rocks east of Squally Point. Located in Figure 6. For explanation, see text.

trix-supported conglomerate with basalt and rare rhyolite clasts $(<4 \mathrm{~cm})$ in a red siltstone matrix; (b) medium clastsupported breccia, principally of basalt with one bed in which rhyolite clasts predominate; (c) a sorted pebble conglomerate, with subrounded rhyolite, siltstone and basalt clasts 2 to $5 \mathrm{~cm}$ in size, interbedded with coarse sandstone; and (d) a hematized siltstone.

\section{Summary of stratigraphic section}

The stratigraphic section of the northern Chignecto peninsula is discontinuous, consisting of basalt and andesite flows interbedded with intrusive rhyolite (perhaps as domes), minor flows, and pyroclastic rocks. Only one major felsic eruptive cycle is recognised (Fig. 7) culminating in a $35-\mathrm{m}$ thick pyroclastic sequence. North-verging thrusts in the volcanic suite both cut and are cut by mafic dykes (Piper et al., 1993) and are preferentially altered.

Minor interbedded sediments are of three types:

(1) Coarse polymictic breccias (Figs. 4, 5B, 9) with blocks more than $1 \mathrm{~m}$ in size suggest the presence of active fault scarps during the accumulation of the volcanic suite. The breccia in Figure 9 is interpreted as developing along a wrench fault associated with thrusting.

(2) Well-sorted polymictic conglomerates and sandstones (Figs. 4, 7, 9), associated with minor red mudstones, are interpreted as fluvial sediments.

(3) Silty mudstones with fine silt laminae, associated with minor conglomerates and limestones (Fig. 4), are a facies association most typical of lakes. The silt laminae are typically 0.5 to $2 \mathrm{~cm}$ thick, slightly wavy and commonly sharp-based. Some beds are graded and both cross lamination and bioturbation are absent. Such laminae resemble lacustrine turbidites.

\section{Petrography and geochemistry}

\section{Petrography}

The petrography of the principal phases of the northern Chignecto peninsula volcanic suite has been described in detail by Pass (1993) and only a brief summary is provided below.

\section{Intrusive and extrusive rhyolite}

Porphyritic rhyolite contains 10 to $20 \%$ phenocrysts 0.2 to $5 \mathrm{~mm}$ in diameter of $\mathrm{K}$-feldspar and in some cases quartz, in an oxidised microcrystalline groundmass. In thin section these rocks show an intense degree of alteration, typically sericitization and chloritization. Many feldspar phenocrysts are embayed and rimmed with quartz crystals. Quartz phenocrysts are dusty and elongate. Many larger feldspar crystals have overgrowths of graphic feldspar. Some chloriterich patches are 2 to $3 \mathrm{~mm}$ in diameter.

Flow banded rhyolite appears similar in thin section, but shows spherulites defining the flow banding. Many spherulites are nucleated on alkali feldspar microphenocrysts.

Coarsely spherulitic rhyolite is similar but has spherules $5 \mathrm{~mm}$ to $10 \mathrm{~cm}$ in diameter. The spherules consist of micro- 
crystalline quartz and feldspar, with a rim of hematite and some vuggy patches filled with chlorite.

The hyaloclastitic rhyolite comprises rubbly flows with epidotized blocks of devitrified rhyolite and lithophysae. Lithophysae have fractured cores filled with quartz and chlorite (Fig. 8B).

\section{Rhyolitic pyroclastic rocks}

At Squally Point, unwelded tuffs contain principally lithic fragments, quartz and feldspar crystals, glass shards, and a microcrystalline matrix that is strongly sericitized and chloritized. The unwelded tuffs pass upwards into ignimbrite that lacks lithic clasts and consists principally of glass shards up to $10 \mathrm{~cm}$ in length that are deformed around quartz and feldspar crystals.

\section{Mafic flows}

Basalt and andesite flows consist of highly altered phenocrysts of plagioclase surrounded by an intersertal groundmass of plagioclase laths and chloritized glass. Amygdules contain quartz and calcite.

\section{Diabase intrusions}

Diabase dykes show either subophitic (plagioclase, pyroxene) or porphyritic ( $3 \mathrm{~mm}$ plagioclase) texture. Pyroxene is commonly altered to chlorite and plagioclase is saussuritised. Rarely the dykes contain amygdules. Small mafic veinlets are associated with larger diabase dykes. These veinlets consist principally of opaque oxide minerals, chlorite and quartz.

\section{Geochemistry}

\section{Description}

Geochemical analyses of representative lithologies from the northern Chignecto peninsula volcanic suite rocks are presented in Table 1 as samples 1 to 44, most of which are located in Figures 2 and 6 . These rocks geochemically resemble other earliest Carboniferous igneous rocks of the western Cobequid Highlands, with more primitive mafic dykes and flows resembling olivine tholeiites and felsic rocks showing A-type granite affinity (e.g., Pe-Piper et al., 1991; PePiper, 1994).

Many of the mafic flows appear partly silicified and a few have strong epidote alteration. Some apparently fresh flows are of basaltic composition (e.g., sample 10) whereas other are andesitic (e.g., sample 40). Silicified flows have as much as $70 \% \mathrm{SiO}_{2}$. Plots of stable elements (Fig. 10) confirm that the primary rocks include both basalt and andesite. The andesite has significantly less iron and magnesium than the basalt (Fig. 11). Some andesite (2 from Seal Cove and 16 from Eatonville Brook) resembles the basalt in having about $0.2 \% \mathrm{P}_{2} \mathrm{O}_{5}$, whereas other andesites (principally from Squally Point) have elevated $\mathrm{P}_{2} \mathrm{O}_{5}(0.6-0.7 \%)$ and rather higher $\mathrm{TiO}_{2}, \mathrm{Nb}$ and $\mathrm{Zr}$ (Fig. 12). Andesites have a more fractionated REE spectrum and most have a small negative Eu anomaly, in contrast to a slight positive anomaly in the basalts (Fig. 13).

Many mafic dykes have relatively high $\mathrm{Ba}(>400 \mathrm{ppm})$, $\mathrm{Zr}(>200 \mathrm{ppm}), \mathrm{TiO}_{2}(>2.5 \%)$ and $\mathrm{P}_{2} \mathrm{O}_{5}(>0.5 \%)$ and $\mathrm{La}$ contents of about $20 \mathrm{ppm}$ (Figs. 11, 12). These dykes show a slight positive Eu anomaly (Fig. 13). Dykes with the largest Eu anomaly $(18,32)$ are less enriched in incompatible elements. In general, $\mathrm{Ni}$ is $<50 \mathrm{ppm}$ and $\mathrm{Cr}<100 \mathrm{ppm}$, suggesting that some fractionation has taken place. A few dykes $(14,18,44)$ have relatively high $\mathrm{Ni}(>60 \mathrm{ppm})$ and $\mathrm{Cr}(>150$ ppm), lower amounts of LIL and HFS elements and have REE spectra similar to those of the basalt flows. Most dykes in the Eatonville area have high $\mathrm{Cu}(>60 \mathrm{ppm})$ and $\mathrm{Co}(>50$ ppm), as does one flow (17).

North of Seal Cove, cross-cutting and structural relationships suggest that the basalt flows (e.g., 10) are oldest, followed by sills (8) and some dykes (e.g., 6) are youngest. The basalts appear to have the least enrichment in most trace elements and the dykes the most, with an increase in both $\mathrm{Rb} / \mathrm{K}$ and $\mathrm{Rb} / \mathrm{Sr}$ but almost constant $\mathrm{Zr} / \mathrm{Y}$. Relationships between incompatible element enrichment and age is less clear in other areas. Some dykes with low incompatible element abundances are demonstrably young; sample 44 cuts sediments (Fig. 9) and sample 30 of intermediate chemical character cuts andesite.

Hyaloclastititic andesite (31) shows enrichment in $\mathrm{Na}_{2} \mathrm{O}$ and $\mathrm{SiO}_{2}$ compared with the correlative massive andesite (41) on the other side of the Squally Point anticline, but trace element composition is almost identical. The hyaloclastitic rhyolites $(27,28)$ show no systematic compositional contrasts with other rhyolites. The silicified andesites (39) show loss of iron and magnesium and enrichment in silica and potassium, but otherwise little systematic compositional change from unaltered andesite $(40,41)$. The epidotised basalt (11) is enriched in $\mathrm{CaO}, \mathrm{Sr}$ and $\mathrm{SiO}_{2}$ and depleted in magnesium and alkalies compared with unaltered basalt (10).

Felsic rocks show substantial variation in REE abundance (Fig. 13) and in most incompatible trace elements (Fig. 12). It is difficult to assess the reasons for this variability. In such fine grained rocks, where accessory minerals are difficult to identify, a detailed interpretation of such variation is not possible. Similar variations are seen in comagmatic granites such as the Pleasant Hills pluton, where temperature is interpreted to play an important role in controlling $\mathrm{Zr}$ fractionation (Pe-Piper, unpublished data).

\section{Interpretation}

The geochemical trends in the mafic dykes (and their extrusive basaltic equivalents) are similar to those reported from mafic dykes cutting granite plutons elsewhere in the western Cobequid Highlands, including the West Moose River pluton (Pe-Piper et al., 1991) and the North River pluton (Pe-Piper, 1991). All show increasing enrichment in incompatible elements with decreasing $\mathrm{Mg}$ number, $\mathrm{Ni}$ and $\mathrm{Cr}$. In the case of the North River pluton, younger dykes are de- 
Table 1. Geochemical analyses

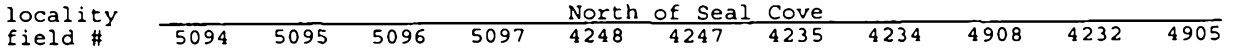

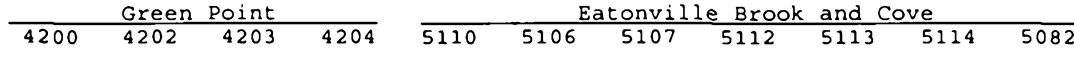

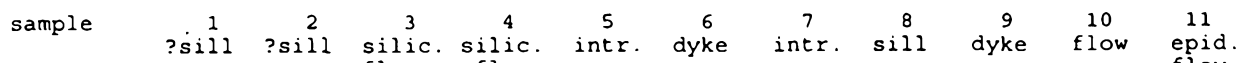
$\begin{array}{ccccccccccc}12 & 13 & 14 & 15 & 16 & 17 & 18 & 19 & 20 & 21 & 22 \\ \text { flow } & \text { tuff } & \text { dyke } & \text { ?intr } & \text { flow } & \text { flow } & \text { dyke } & \text { dyke } & \text { dyke } & \text { wide } & \text { dyke }\end{array}$ Major elements by XRF (wt

\begin{tabular}{|c|c|c|c|c|c|c|c|c|c|c|c|}
\hline $\mathrm{iO}_{2}$ & 49.23 & 59.82 & 69.32 & 58.88 & 76.33 & 45.52 & 76.18 & 48.03 & & 46.87 & 50.09 \\
\hline $\mathrm{TiO}_{2}$ & 2.52 & 1.71 & 0.59 & 0.84 & 0.15 & 3.9 & 0. & & & & .28 \\
\hline $\mathrm{Al}_{2} \mathrm{O}_{1}$ & 15.31 & 14.73 & 14.68 & 18.17 & 11.02 & 13.23 & 11.63 & 13.58 & & 7 & .89 \\
\hline$=2 \mathrm{O}_{3}$ & 13.12 & 8.41 & 4.03 & 6.79 & 1.53 & 14.91 & 2.27 & 12.64 & & 11.03 & $\begin{array}{l}11.24 \\
\text { 11. }\end{array}$ \\
\hline $\mathrm{MnO}$ & 0.61 & 0.20 & 0 & 0.14 & 0.06 & 0.96 & 0.05 & 0.39 & .0 & 0.21 & \\
\hline go & 5.67 & 2.69 & 1.81 & 2.97 & 0.99 & 4.95 & 0.84 & 6 & 0.26 & 8.36 & 0.37 \\
\hline $\mathrm{CaO}$ & 3.88 & 3.13 & 1 & 1.63 & $1+2$ & 7.01 & .03 & 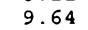 & 0.38 & 8.08 & 17.67 \\
\hline $\mathrm{Na}_{2} \mathrm{C}$ & 2.72 & 3.96 & 4.48 & 6.57 & 2 & 1 & 3.71 & 2. & 1.17 & 2.19 & 0.13 \\
\hline $\mathrm{K}_{2} \mathrm{O}$ & 2.78 & 3.18 & 2.34 & 1.31 & 5.11 & 1.97 & 3.92 & 1.20 & 5.71 & 1.21 & 0.04 \\
\hline $\mathrm{O}$ & 0.43 & 0.57 & 0.12 & 0.16 & 0.03 & 0.69 & 01 & & 0.02 & & 0.15 \\
\hline & 3.90 & 1.90 & 1.80 & 2.30 & 1.10 & 3.10 & 0.50 & 1.60 & .70 & 3.60 & \\
\hline
\end{tabular}
$\begin{array}{rrrrrrrrrrr}49.72 & 73.25 & 51.00 & 72.89 & 60.22 & 45.80 & 46.08 & 47.30 & 47.09 & 44.36 & 47.49 \\ 3.87 & 0.21 & 1.61 & 0.28 & 1.03 & 1.85 & 1.87 & 3.29 & 3.42 & 2.92 & 3.41 \\ 12.97 & 11.97 & 15.02 & 13.43 & 12.27 & 18.49 & 16.15 & 13.06 & 13.09 & 14.62 & 13.17\end{array}$ $\begin{array}{rrrrrrrrrrr}12.97 & 11.97 & 15.02 & 13.43 & 12.27 & 18.49 & 16.15 & 13.06 & 13.09 & 14.62 & 13.17 \\ 13.34 & 2.36 & 9.98 & 2.70 & 6.13 & 13.49 & 13.60 & 15.03 & 15.29 & 15.30 & 14.91 \\ 0.32 & 0.06 & 0.19 & 0.05 & 0.14 & 0.25 & 0.31 & 0.66 & 0.83 & 0.42 & 0.50\end{array}$ $\begin{array}{lllllllllll}4.68 & 0.84 & 6.88 & 0.90 & 2.39 & 6.37 & 7.92 & 5.60 & 5.29 & 8.04 & 5.61 \\ 5.36 & 0.28 & 6.89 & 0.11 & 6.80 & 6.59 & 9.20 & 9.34 & 8.61 & 5.66 & 8.63\end{array}$ $\begin{array}{lllllllllll}3.67 & 2.92 & 2.14 & 3.36 & 2.77 & 3.33 & 2.08 & 2.35 & 2.39 & 3.15 & 2.72 \\ 0.61 & 5.47 & 2.40 & 5.05 & 1.67 & 0.26 & 0.45 & 1.34 & 1.36 & 0.91 & 0.96\end{array}$

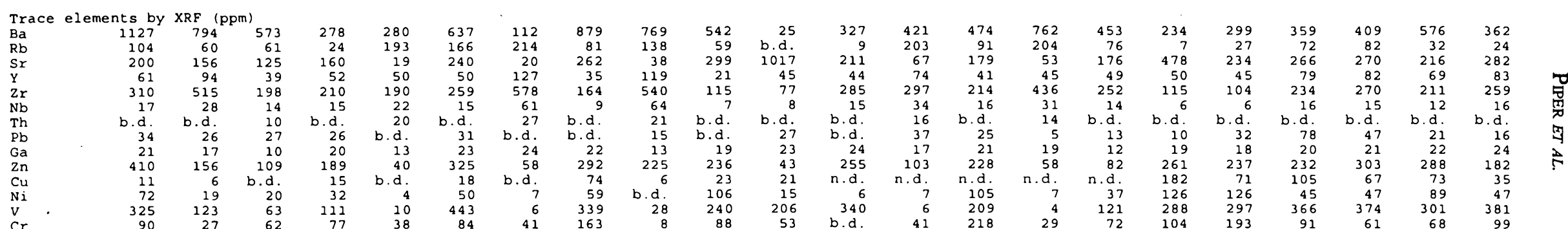

Cr

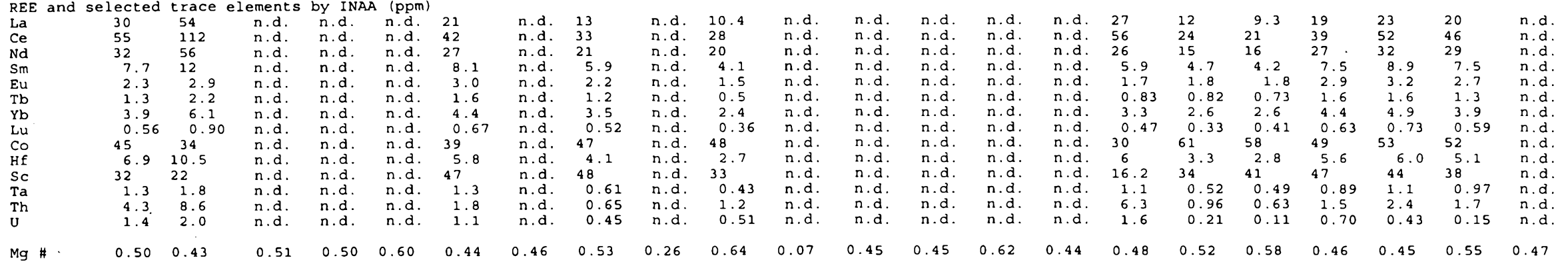

b.d. = below detection limit; $n . d .=$ not determined 
Table 1. Continued

locality field

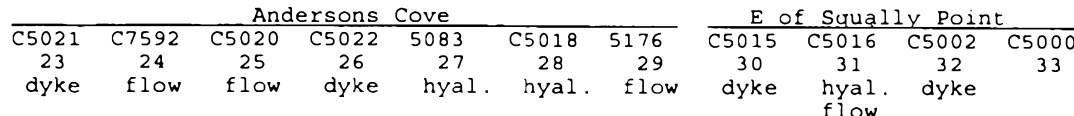

Major elements by XRF (wt $\%$ )

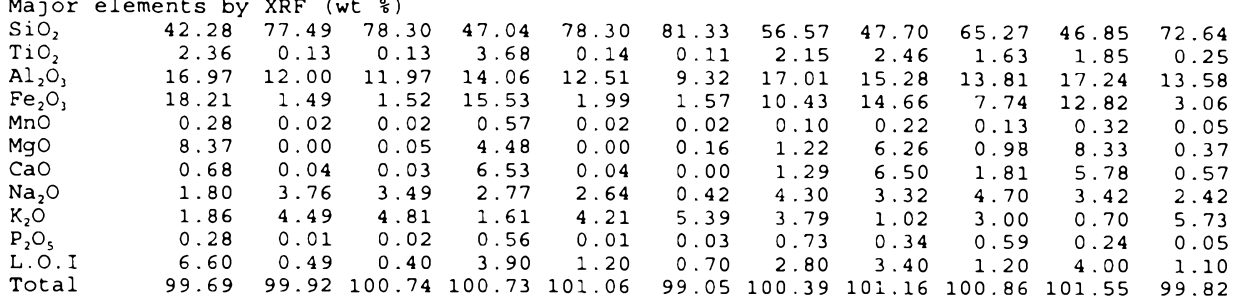

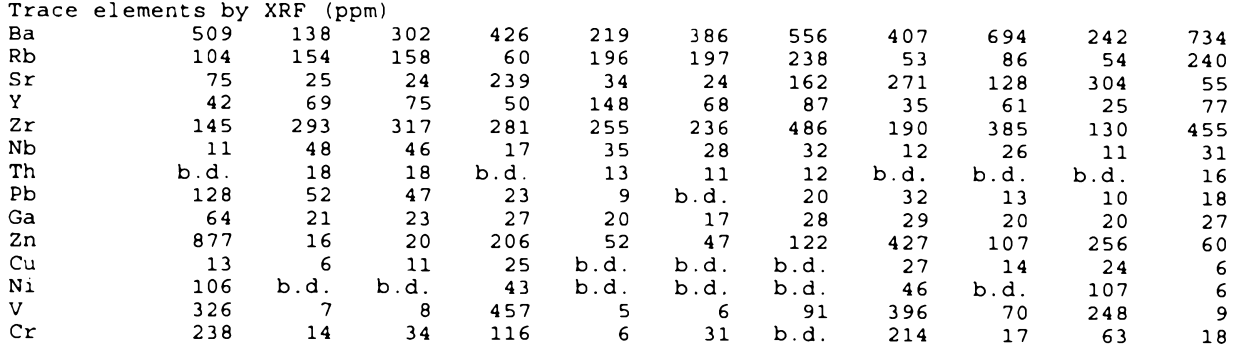

REE and selected trace elements by INAA (ppm, except Au in ppb)

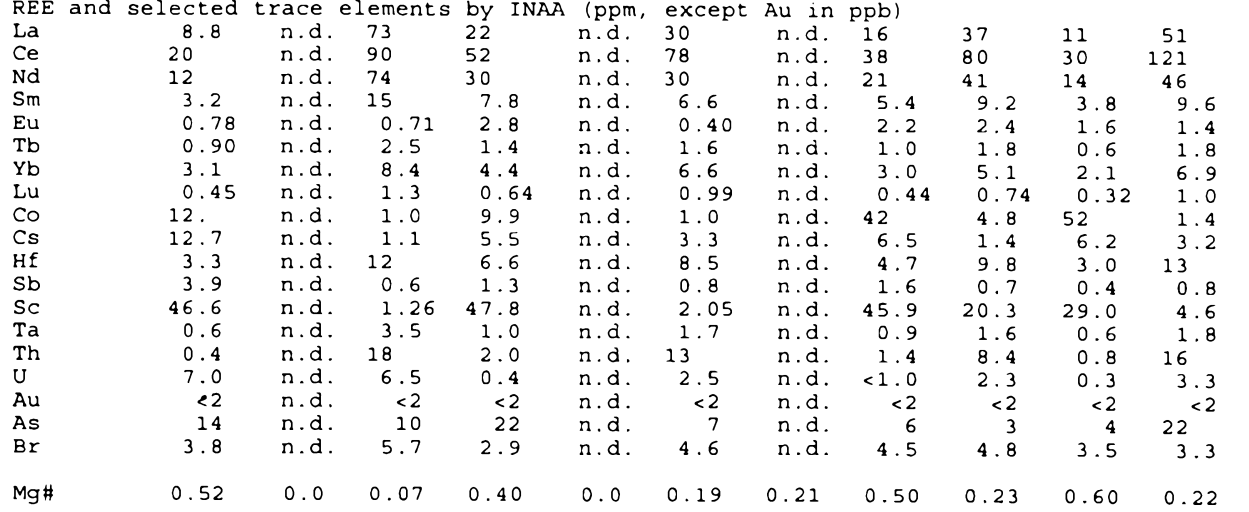

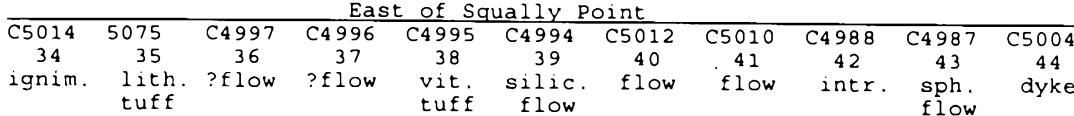

$\begin{array}{lllllllllll}71.67 & 73.18 & 80.19 & 78.62 & 76.07 & 66.19 & 61.75 & 61.58 & 79.40 & 73.18 & 49.67\end{array}$

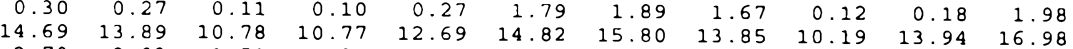
$\begin{array}{rrrrrrrrrrr}2.70 & 2.03 & 1.51 & 1.20 & 2.41 & 6.59 & 9.58 & 8.29 & 1.78 & 2.37 & 11.24 \\ 0.05 & 0.03 & 0.01 & 0.02 & 0.03 & 0.03 & 0.18 & 0.14 & 0.02 & 0.03 & 0.29\end{array}$ $\begin{array}{lllllllllll}0.38 & 0.18 & 0.01 & 0.02 & 0.47 & 0.29 & 1.60 & 1.90 & 0.18 & 0.14 & 5.90 \\ 0.16 & 0.10 & 0.01 & 0.27 & 0.03 & 0.95 & 1.58 & 3.11 & 0.00 & 0.13 & 8.03\end{array}$ $\begin{array}{lllllllllll}2.17 & 2.13 & 3.51 & 2.70 & 0.05 & 3.33 & 3.58 & 3.11 & 0.00 & 0.13 & 5.03 \\ 6.41 & 5.99 & 3.94 & 4.97 & 5.12 & 4.44 & 2.47 & 3.69 & 0.24 & 3.62 & 2.66\end{array}$ $\begin{array}{lllllllllll}6.41 & 5.99 & 3.94 & 4.97 & 5.12 & 4.44 & 2.47 & 3.69 & 6.24 & 4.40 & 1.20 \\ 0.06 & 0.03 & 0.02 & 0.02 & 0.05 & 0.64 & 0.67 & 0.59 & 0.02 & 0.02 & 0.30\end{array}$

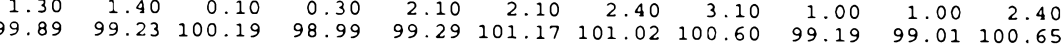

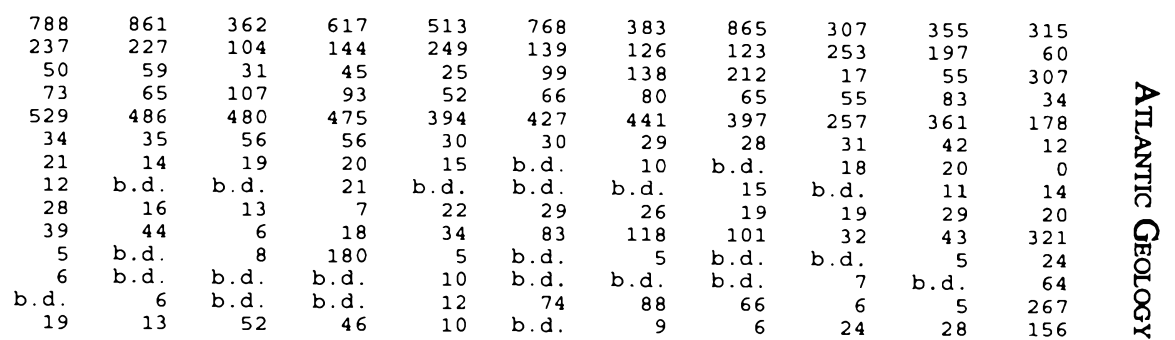

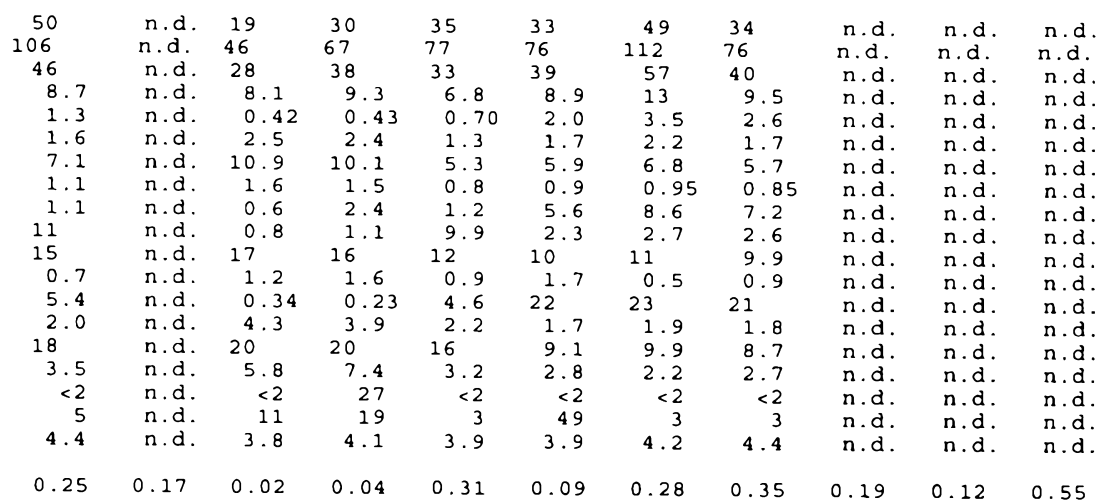




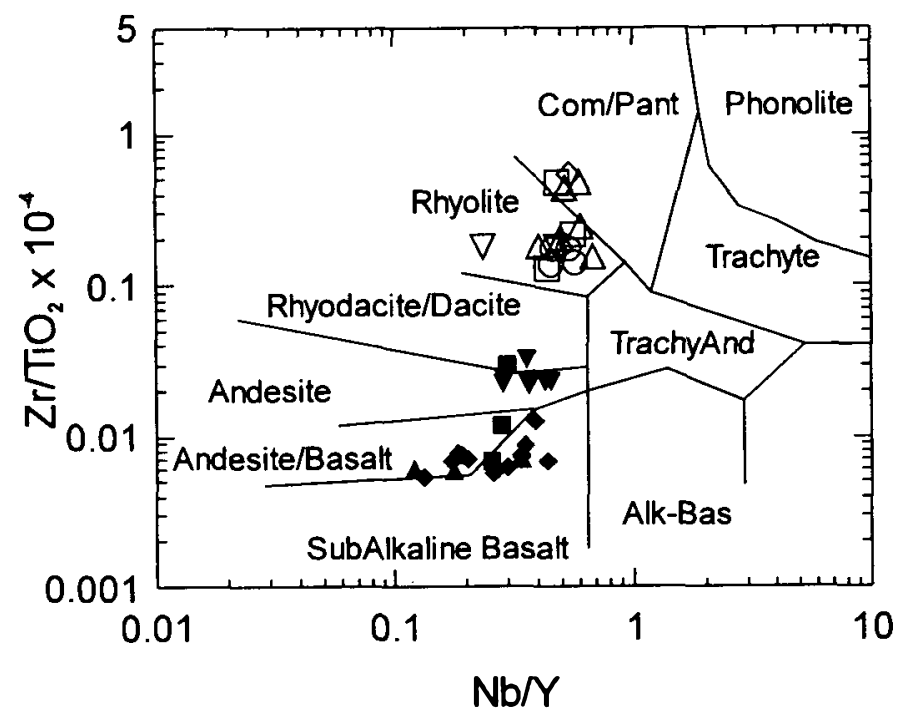

\begin{tabular}{ll} 
MAFIC ROCKS & \multicolumn{1}{c}{ FELSIC ROCKS } \\
basalt flow & $\circ$ pyroclastic rocks \\
- andesite flow & $\square$ intrusion \\
- dyke & $\triangle$ flow \\
- sill & $\nabla$ hyaloclastite \\
& $\diamond$ dyke
\end{tabular}
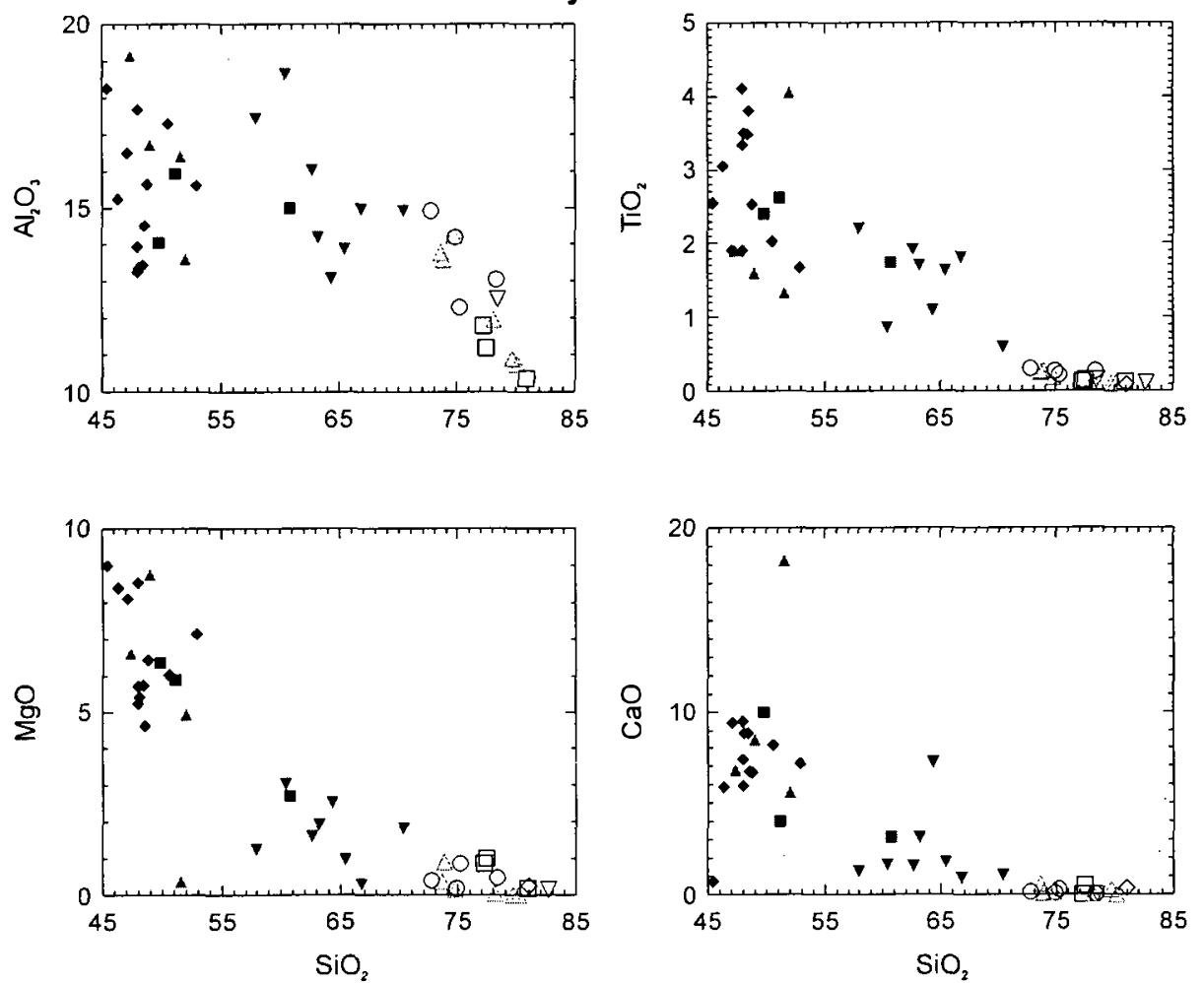

Fig. 11. Harker diagrams of selected major elements plotted against $\mathrm{SiO}_{2}$. Legend as in Figure 10.

monstrably progressively more enriched in incompatible elements. Pe-Piper et al. (1991) demonstrated the role of olivine and pyroxene fractionation, with lesser fractionation of iron-titanium oxides, in the evolution of the dyke rocks. The positive Eu anomaly in some mafic dykes requires addition of plagioclase, either derived from cumulates in crustal magma chambers or from contamination by residual hot plagioclase-2 pyroxene-garnet granulite at the base of the crust
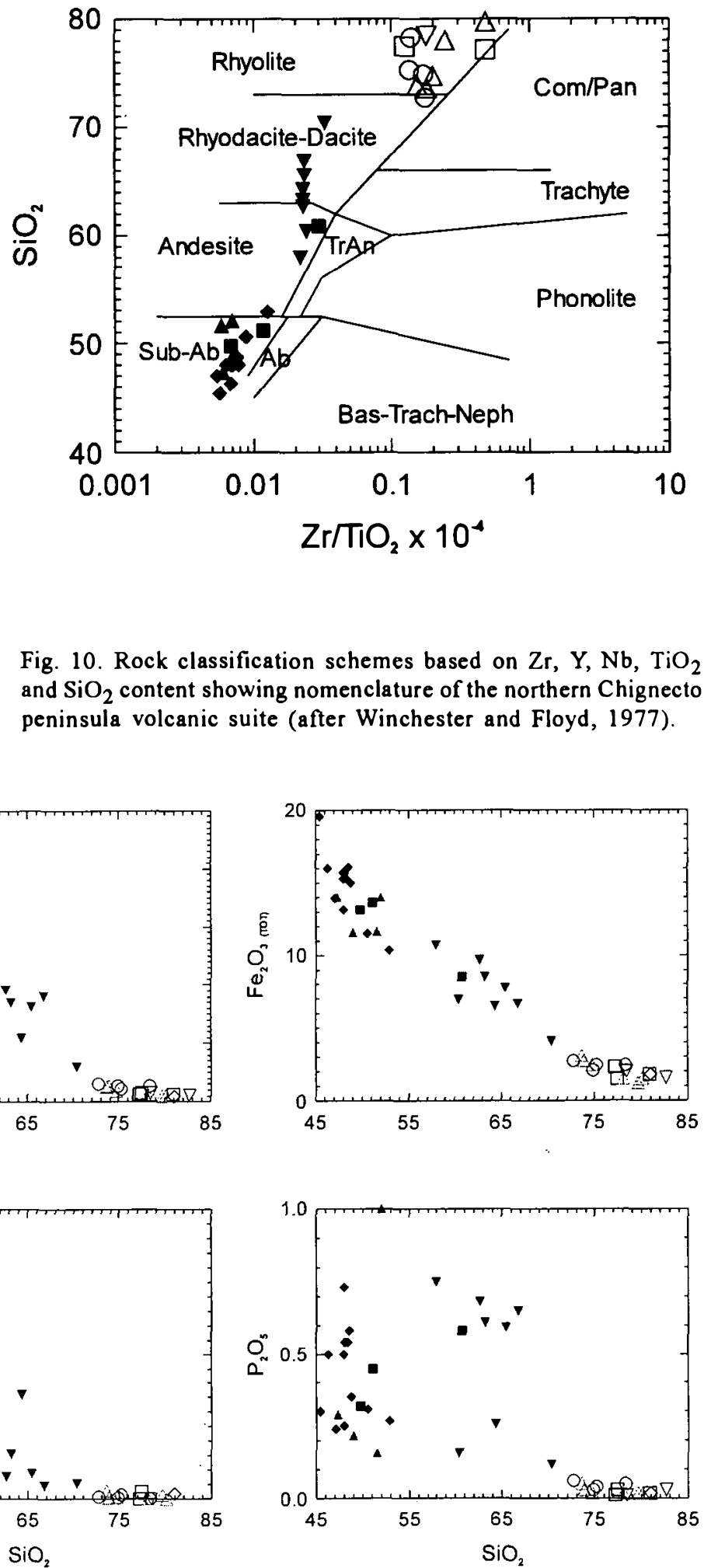

Fig. 10. Rock classification schemes based on $\mathrm{Zr}, \mathrm{Y}, \mathrm{Nb}, \mathrm{TiO}_{2}$ and $\mathrm{SiO}_{2}$ content showing nomenclature of the northern Chignecto peninsula volcanic suite (after Winchester and Floyd, 1977).

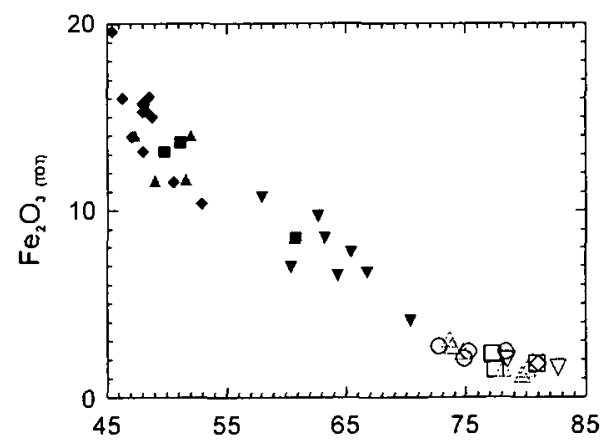

from which large volumes of granitic partial melt (with strongly negative Eu anomalies) had been extracted. This mechanism has been suggested by Emslie and Stirling (1993) for anorthosites associated with rapakivi granite in the Nain plutonic suite. The presence of granulite xenoliths at Clarke Head (Gibbons and Murphy, 1995) may be direct evidence of this process.

The two types of andesite mirror the two main types of 

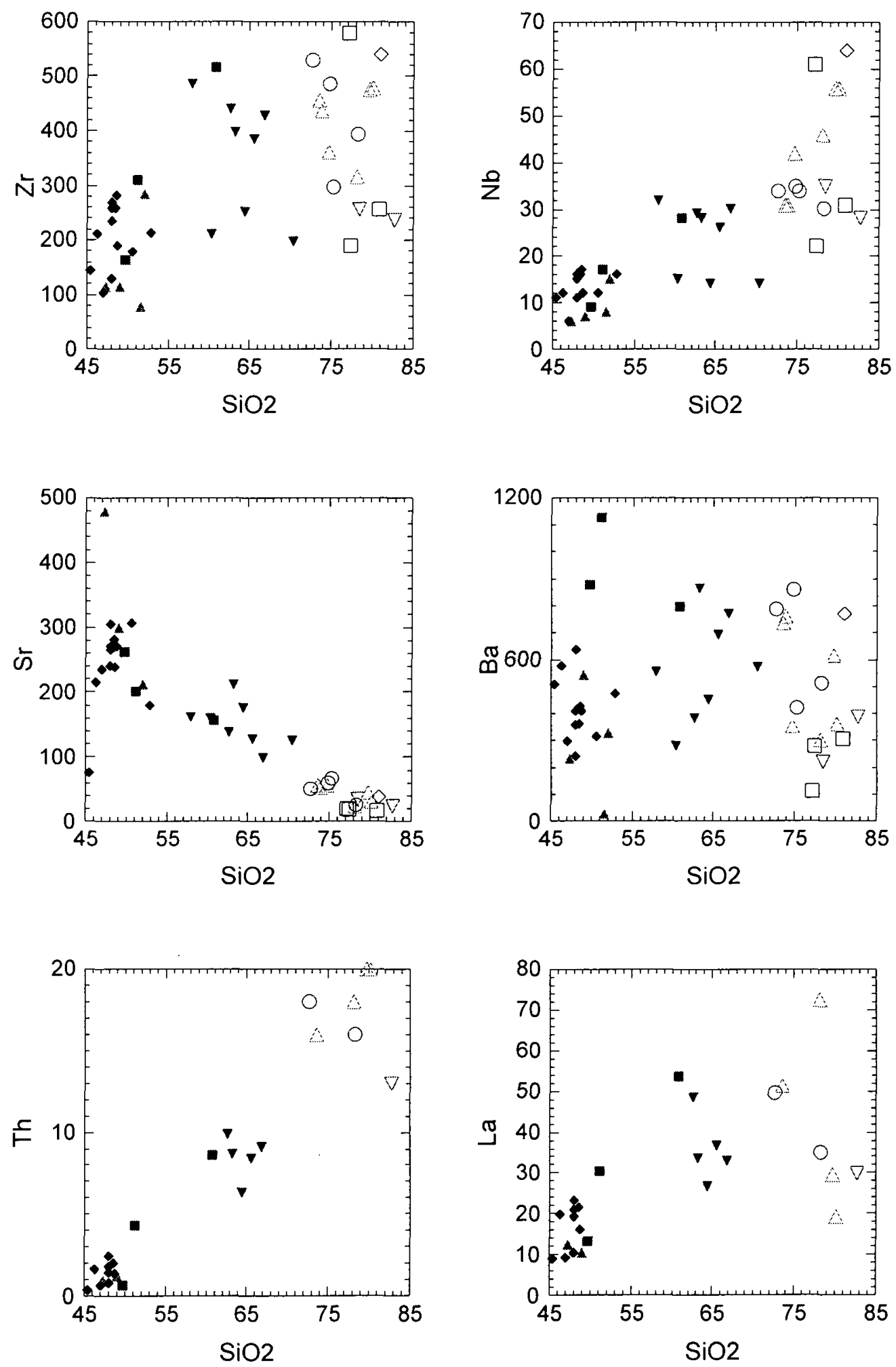

Fig. 12. Harker diagrams of selected trace elements plotted against $\mathrm{SiO}_{2}$. Legend as in Figure 10.

dyke rock in their enrichment in incompatible elements. Two hypotheses can be considered for their origin. (1) They may be derived by assimilation and fractional crystallisation (AFC) from basaltic parents, probably involving mixing with felsic magma, which Pe-Piper et al. (1991) argued was derived from partial melting of lower crust. Highly elevated concentrations of $\mathrm{Al}, \mathrm{P}, \mathrm{Ba}$ and $\mathrm{Zr}$ in some samples make this hypothesis unlikely, as does the general lack of dacitic rocks (Fig. 10A; apparent dacites in Figure 10B result from silicification altering $\mathrm{SiO}_{2}$ contents). (2) The widespread occurrence of hornblende gabbro intrusions in the Cobequid Highlands (Donohoe and Wallace, 1985; Piper et al., 1993) suggests an alternative explanation. The andesite may be derived from partial remelting of underplated hydrous gab- 

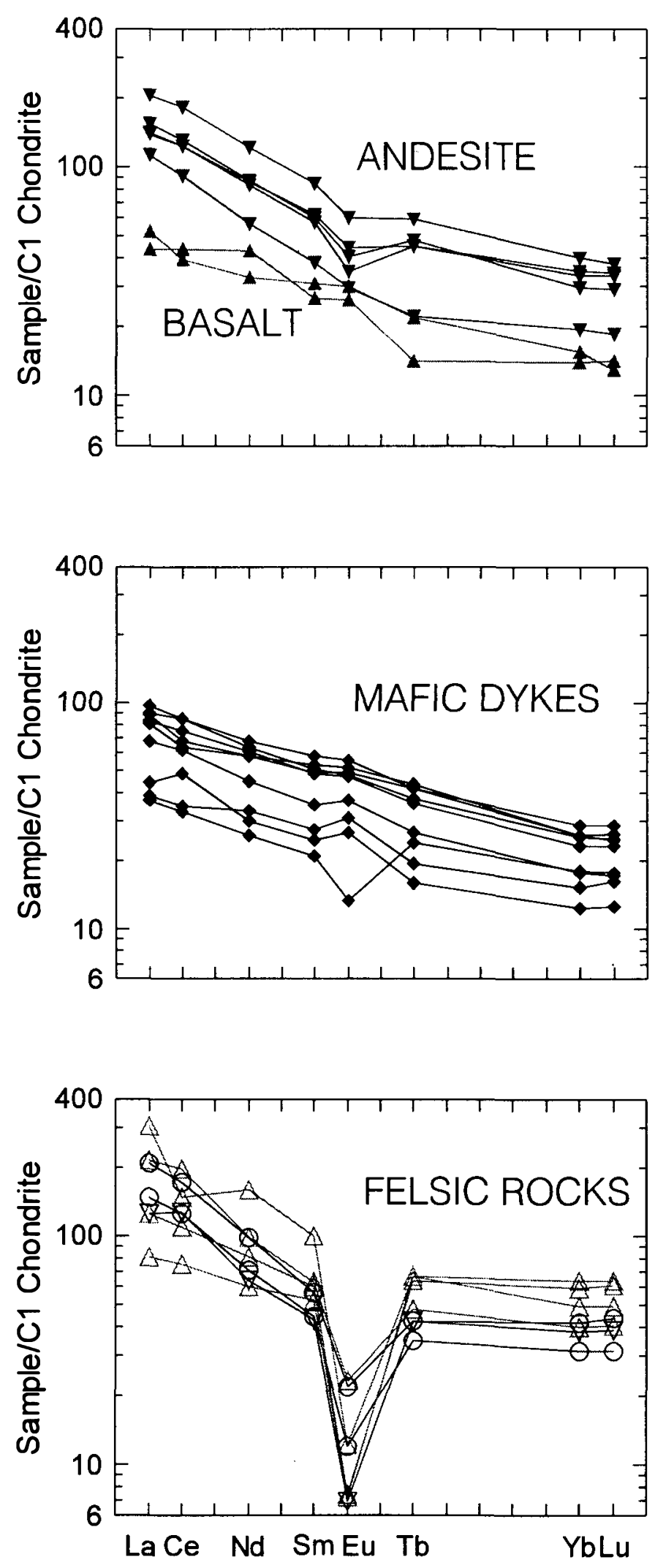

Fig. 13. Representative REE plots for the northern Chignecto peninsula volcanic suite. Legend as in Figure 10.

broic rocks, to produce high-alumina andesite enriched in incompatible elements from the source rock (e.g., Nicholls and Ringwood, 1973; Beard and Lofgren, 1989). The en- richment in $\mathrm{Zr}$ in andesite compared with basalt would require about $25 \%$ partial melting at $900^{\circ} \mathrm{C}$. The syn-magmatic thrusting could have created conditions of local crustal thickening and remelting of underplated gabbro (Fig. 14B).

The alteration patterns seen in the volcanic suite are characteristic of low-temperature hydrothermal circulation. Silicification of all types of volcanic rock was accompanied by loss of iron and increase in potassium. The enrichment of hyaloclastitic andesite in $\mathrm{Na}_{2} \mathrm{O}$ suggests extrusion into a sodic lake or marine waters. No other evidence for saline conditions has been found, and the sediment facies are more consistent with a lacustrine rather than a marine origin.

\section{SYNTHESIS OF THE VOLCANIC ENVIRONMENT}

The Fountain Lake Group on the Cape Chignecto peninsula consists of a volcanic-subvolcanic succession with minor interbedded sediments. The igneous rocks are geochemically similar to those of the Cape Chignecto pluton and other plutons of the western Cobequid Highlands. The felsic magmas show A-type affinity and have been interpreted as lower crustal melts, with a heat source from gabbroic magma produced during extension of the Magdalen basin (Fig. 14B).

Evidence of northward thrusting during emplacement of the volcanic suite has been documented by Piper $e t$ al. (1993), who showed that late dykes cut brittle thrust planes. Analogous ductile thrusting in the Cape Chignecto pluton was described by Waldron et al. (1989). Fault scarp breccias formed along north-northeast-trending wrench faults and were intruded by late dykes (Figs. 9, 14A).

The sedimentary environment included lakes into which both rhyolite and mafic lavas flowed (Fig. 14A). Coarse polymict breccias (Figs. 4, 5B) suggest the presence of active fault scarps during the accumulation of the volcanic suite. Some sorted conglomerates indicate the presence of fluvial sedimentation.

Mafic dykes with positive Eu anomaly may record the contamination of gabbroic magma by additional plagioclase from residual base-of-crust plagioclase-pyroxene granulite from which felsic magma had been extracted. Fractionation of this mafic magma resulted in enrichment in incompatible elements. Magma probably evolved in discrete batches, since there is no simple time sequence of magma type and some of the latest dykes are relatively unfractionated. Andesites are common, but dacites are absent. Incompatible element enrichment in andesites mimics that in the various mafic dykes: andesites may be derived from a mafic parent either by fractionation or by partial remelting of underplated gabbro. We are currently obtaining stable isotope data to distinguish these two hypotheses.

\section{ACKNOWLeDgements}

We thank all those who have increased our understanding of these sections from discussions in the field, including John Waldron, Howard Pancura, and Steve McCutcheon. Work supported by NSERC grants to G. Pe-Piper and GSC funding to D.J.W. Piper, including funds from the Canada- 

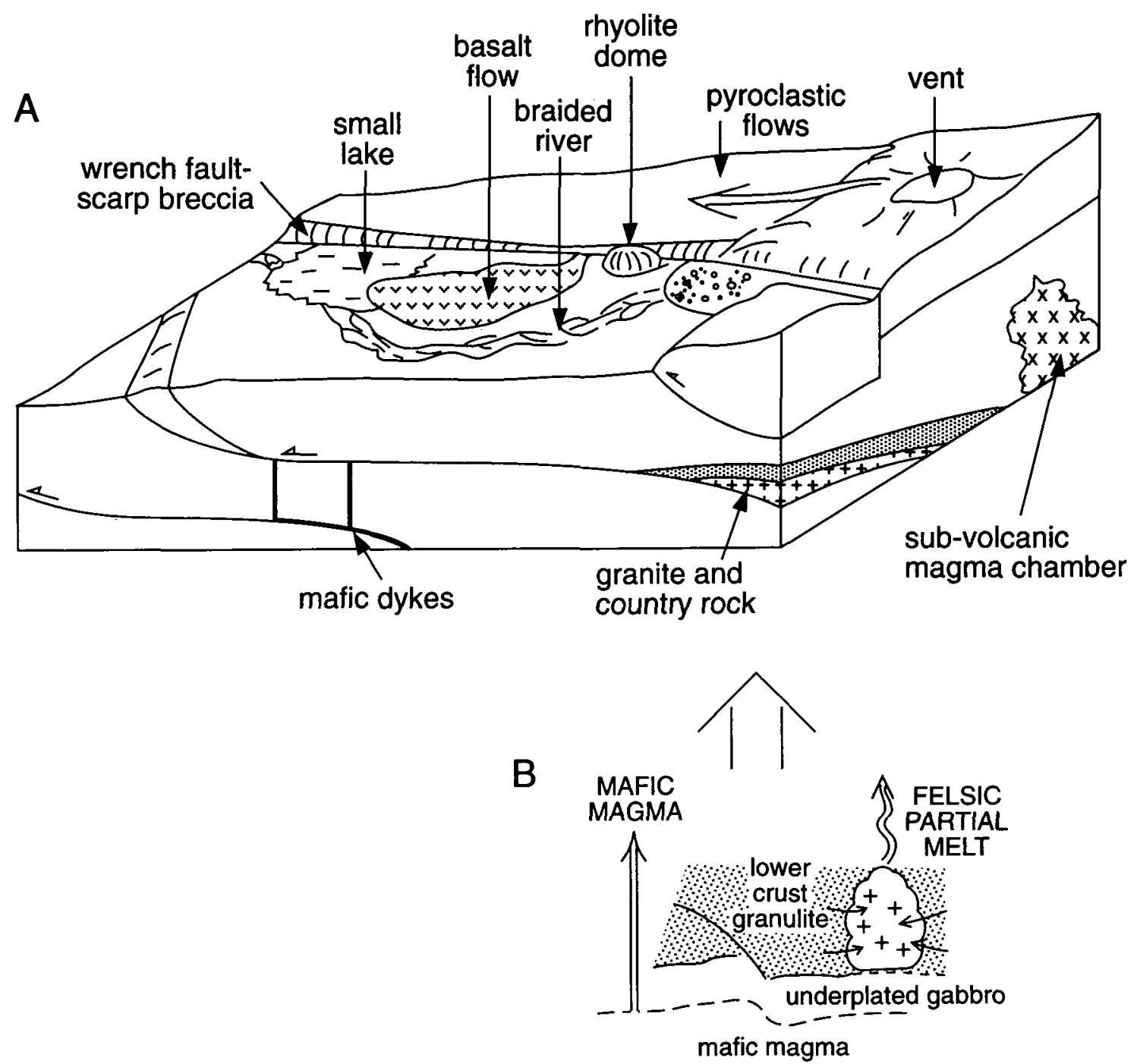

Fig. 14. Schematic block diagram showing an interpretation of the evolution of the volcanic rocks of the northern Chignecto peninsula. (A) Surface conditions showing development of sedimentary and volcanic facies in relation to thrust and wrench faulting. (B) Speculative conditions at the base of the crust. For explanation, see text.

Nova Scotia Cooperation Agreement on Mineral Development. An early version of this manuscript was reviewed by Peter Giles and Ken Skene. Journal referees Peter Wallace and A.K. Chatterjee improved the manuscript.

BEARD, J.S. and LOFGRen, G.E. 1989. Effect of water on the composition of partial melts of greenstone and amphibolite. Science, 244, pp. 195-197.

Donohoe, H.V. and Wallace, P.I. 1982. Geological map of the Cobequid Highlands, Nova Scotia. Scale 1:50 000. Nova Scotia Department of Mines and Energy.

---- 1985. Repeated orogeny, faulting and stratigraphy of the Cobequid Highlands, Avalon Terrane of northern Nova Scotia. Geological Association of Canada - Mineralogical Association of Canada, Joint Annual Meeting, Guidebook 3, Fredericton, New Brunswick, 77 p.

EMSLIE, R.F. and STIRLING, J.A.R. 1993. Rapakivi and related granitoids of the Nain plutonic suite: geochemistry, mineral assemblages and fluid equilibria. The Canadian Mineralogist, 31, pp. 821-847.

Gibbons, W. and MURPhy, J.B. 1995. Mylonitic mafic granulite in fault megabreccia at Clarke Head, Nova Scotia: a sample of Avalonian lower crust? Geological Magazine, 132, pp. 81-90.

Nicholls, I.A. and Ringwood, A.E. 1973. Effect of water on olivine stability in tholeiites and the production of silica-saturated magmas in the island arc environment. Journal of Geology, 81 , pp. $285-300$.

PAss, D.J. 1993. Late Paleozoic volcanic stratigraphy and structural history of Squally Point and vicinity, western Cobequid Highlands, Nova Scotia. B.Sc. (Honours) thesis, Saint Mary's University, Halifax, Nova Scotia, 88 p.

Pe-Piper, G. 1991. Granite and associated mafic phases, North River pluton, Cobequid Highlands. Atlantic Geology, 27, pp. 15-28.

-.-- 1994. The Carboniferous plutons and associated igneous rocks of the western Cobequid Highlands, Nova Scotia. Report to the Geological Survey of Canada, 84 p. +4 maps.

PE-PIPER, G. and PIPER, D.J.W. 1989. The upper Hadrynian Jeffers Group, Cobequid Hills, Avalon Zone of Nova Scotia: a backarc volcanic complex. Geological Society of America Bulletin, 101, pp. 364-376.

Pe-Piper, G., Piper, D.J.W., and Clerk, S.B. 1991. Persistent 
mafic igneous activity in an A-type granite pluton, Cobequid Highlands, Nova Scotia. Canadian Journal of Earth Sciences, 28, pp. 1058-1072.

Piper, D.J.W., Pe-Piper, G., and Loncarevic, B.D. 1993. Devonian - Carboniferous deformation and igneous intrusion in the Cobequid Highlands. Atlantic Geology, 29, pp. 219-232.

Ryan, R.J., Boehner, R.C., and Deal, A. 1990. Cumberland basin geology map, Apple River and Cape Chignecto, Cumberland County. Nova Scotia Department of Mines and Energy, Map 90-11, 1:50 000 scale.

Salas, C.J. 1986. Braided fluvial architecture within a rapidly subsiding basin: the Pennsylvanian Cumberland Group southwest of Sand River, Nova Scotia. M.Sc. thesis, University of Ottawa, 351 p. and 8 maps.
Waldron, J.G.F., Piper, D.J.W., and Pe-Piper, G. 1989. Deformation of the Cape Chignecto Pluton, Cobequid Highlands, Nova Scotia: thrusting at the Meguma-Avalon boundary. Atlantic Geology, 25, pp. 51-62.

Winchester, J.A. and Floyd, P.A. 1977. Geochemical discrimination of different magma series and their differentiation products using immobile elements. Chemical Geology, 20, pp. 325-343.

Editorial responsibility: P.S. Giles and G.L. Williams 